\title{
Pembelajaran IPA Berbasis Integrasi Islam-Sains pada Pokok Bahasan Penciptaan Alam Semesta dan Tata Surya
}

\author{
Richa Dwi Rahmawati \\ Nurhasanah Bakhtiar \\ Magister Pendidikan Guru Madrasah Ibtidaiyah Universitas Islam Negeri Sultan Syarif \\ Kasim Riau, Indonesia \\ e-mail: \\ richadwi23@gmail.com \\ nurhasanahbakhtiar@uin-suska.ac.id
}

\begin{abstract}
.
This research aims to explore science-based learning in Islamic-Science integration on the subject matter of the creation of the universe and the solar system. This research is library research. The data source used is literature related to the creation of the universe and the solar system and is associated with the verses of the Qur'an and the hadith of the Prophet who talk about the creation of the universe. For this reason, the data analysis used is the content of the analysis with a qualitative approach. The data obtained through reading various sources are selected first, then categorized and then analyzed. The results of this study are learning science in natural creation material and the solar system has a relationship with Islamic studies. It is stated that nature was created by one unit until an explosion occurred (Bigbang Theory), while what has been mentioned in the Qur'an is very characteristic as an entity separated by Allah. Thus science learning that is integrated with Islam can increase scientific insight while strengthening religious beliefs.
\end{abstract}

Key Words: Integrated, Science, The Creation of Nature, Solar System.

\begin{abstract}
ABSTRAK.
Penelitian ini bertujuan untuk mengeksplor pembelajaran IPA berbasis integrasi Islam-Sains pada pokok bahasan penciptaan alam semesta dan tata surya. Penelitian ini merupakan penelitian kepustakaan (library research). Sumber data yang digunakan adalah literatur yang terkait penciptaan alam semesta dan tata surya dan dikaitkan dengan ayat-ayat al-Qur'an dan hadis Rasul yang membicarakan tentang penciptaan alam semesta. Untuk itu analisis data yang dipakai adalah content analisys dengan pendekatan kualitatif. Data-data yang diperoleh melalui bacaan berbagai sumber diseleksi terlebih dahulu, kemudian dikategorisasi dan dianalisis selanjutnya diambil kesimpulan. Hasil penelitian ini adalah Pembelajaran sains pada materi penciptaan alam dan tata surya memiliki hubungan dengan studi Islam. Dinyatakan bahwa alam diciptakan oleh satu unit sampai sebuah ledakan terjadi (Teori Bigbang), sementara apa yang telah disebutkan di dalam Al-Qur'an adalah sifat sekali sebagai suatu entitiy yang dipisahkan oleh Allah. Dengan demikian pembelajaran sain yang terintegrasi dengan Islam dapat menambah wawasan keilmuwan sekaligus memperkuat keyakinan keberagamaan.
\end{abstract}

Kata Kunci: Terpadu, Sains, Penciptaan Alam, Tata Surya 


\section{PENDAHULUAN}

Pendidikan adalah segala daya upaya dan semua usaha untuk membuat masyarakat dapat mengembangkan potensi peserta didik agar memiliki kekuatan spiritual keagamaan, pengendalian diri, berkepribadian, memiliki kecerdasan, berakhlak mulia, serta memiliki keterampilan yang diperlukan sebagai anggota masyarakat dan warga negara (Rini: 2). Salah satu upaya untuk meningkatkan kualitas pendidikan adalah dengan adanya pengembangan kurikulum. Kurikulum sebagai instrumen yang membantu guru untuk memenuhi kebutuhan peserta didik dan kebutuhan masyarakat (Hayat, 2013: 19).

Kurikulum terbarukan yaitu kurikulum 2013, Kurikulum 2013 mencoba memberikan perhatian yang sama terhadap pendidikan agama dengan pendidikan umum, ibarat seorang penjelajah "sedayung satu dua pulau terlampaui" mungkin kiasan ini yang kiranya tepat disematkan dalam kurikulum 2013. Hal ini karena melihat konsep dasar dari kurikulum 2013 yang mencoba mengintegrasikan beberapa pelajaran ke dalam tema besar berdasarkan standar kompetensi yang dimiliki masing-masing pelajaran. Dengan model seperti ini siswa diharapkan dapat memahami konsep dasar secara utuh berdasarkan kehidupan nyata yang ada di sekitarnya, dengan kata lain antara materi pembelajaran dan kehidupan nyata selalu beriringan dan saling memberi penguat antara keduanya. (Miftah: 2017:198).

Bentuk aplikatif dari kurikulum 2013 adalah adanya integrasi dalam pembelajaran. Integrasi dapat diterapkan pada mata pelajaran. Namun, dalam menerapkan integrasi dalam sebuah pembelajaran diperlukan kerja sama yang baik antara guru, siswa, dan sekolah. Maka dari itu, untuk bahan ajar dalam pembelajaran juga perlu disiapkan terlebih dahulu yang sesuai dan dapat dilakukan integrasi, agar tidak terjadi kesalahpahaman dalam proses pembelajaran. Penerapan integrasi sejauh ini dalam kurikulum K13 hanya dilakukan secara general saja tidak keseluruhan dan mendalam. Seorang guru bidang studi pun harus mengetahui konsep dari integrasi tersebut.

Konsep integrasi harus diterapkan dengan "nilainisasi" jadi siswa tidak hanya mempelajari pengetahuan tetapi juga nilai-nilai yang terkandung di dalamnya. Dalam pembelajaran IPA, mengenai topik bahasan penciptaan alam semesta dan tata surya di integrasikan dengan ilmu Islam berdasarkan Al-Quran, sehingga ditemukan akar benang merah dari integrasi kedua kajian ilmu tersebut. Dengan adanya integrasi diharapkan dapat memudahkan dan menambah wawasan siswa dalam keterkaitan suatu kajian ilmu dengan ilmu lainnya yang saling melengkapi.

Integrasi dalam pembelajaran IPA dilakukan dengan tujuan untuk menghilangkan dikotomi antara ilmu umum dan ilmu agama, sehingga saling menguatkan saling mendukungnya pengetahuan umun dana ajaran agama islam, karena seseungguhnya kajian pada poko bahasan penciptaan alam semesta dan tata surya sudah ada sejak 14000 tahun yang lalu, sudah diceritakan dalam Al-Qur'an hanya saja peneliti secara keilmuan baru menemukannya dengan data empiriknya. Tujuan penelitian ini ingin membuat garis besar bagaimana konsep integrasi dalam mata pelajaran IPA khsunya pada topik penciptaan alam semsta dan tata surya.

Penerapan konsep integrasi dalam setiap materi mengenai penciptaan alam semsta dan tata surya dapat membuat siswa menjadi bersemangat dalam proses belajar mengajar. Guru juga sidah sewajarnya melakukan inovasi dengan cara integrasi agar proses belajar mengajar menjadi kondusif dan memiliki value yang baik. 


\section{KAJIAN LITERATUR}

\section{Konsep Integrasi Sains dan Islam}

Secara bahasa integrasi yang berarti "penyatuan" dilawankan maknanya dengan "pemisahan"; suatu sikap yang meletakkan tiap-tiap bidang kehidupan ini dalam kotakkotak yang berlainan, namun inheren agama dan sains merupakan sebuah keniscayaan, bahkan berlangsung secara masif dan cenderung antagonistis (Amril, 2016:2). Integrasi menurut M.Amin Abdullah adalah sebuah paradigma keilmuan yang mengasumsikan bahwa peleburan dan pelumatan yang satu ke dalam yang lainnya, baik dengan cara meleburkan sisi normativitas-sakralitas keberagaman secara menyeluruh masuk ke wilayah "historisitas-profanitas" atau sebaliknya (Amril. 2016:4)

Upaya integrasi juga tidak dapat dilepaskan dari upaya internalisasi nilai yang terjalin dengan ilmu, yaitu nilainisasi. Nilainisasi yang di maksud di sini adalah dalam proses pembelajaran tidak hanya terjadi pertukaran informasi dan pengetahuan saja tetapi juga transfer nilai-nilai yang terkandung dalam proses pembelajaran tersebut (Amri, 2016:6). Konsep Integrasi sebenarnya adalah dalam bentuk integrasi-interkoneksi. Integrasi adalah sebuah keniscayaan atau keharusan. Sedangkan interkoneksi adalah sebuah pendekatan keilmuan apapaun itu yang tidak dapat berdiri sendiri. Jadi integrasi-interkoneksi adalah sebuah pendekatan yang mengupayakan atau menekankan bahwa semua bidang keilmuan memiliki saling keterkaitan.

Saling keterkaitan inilah yang disebut dengan sebuah keniscayaan mengingat sesuatu yang dibidik oleh disiplin keilmuan objek materialnya dapat saja sama meskipun objek formalnya berbeda, maksudnya adalah objek material (objek yang menjadi sasaran penelitian penyelidikan), objek formal (sudut pandang yang ditujukan dari penelitian tersebut). Sebagai contoh seseorang yang ingin meneliti mengani manusia (objek material) kemudian mengkaji manusia tersebut dengan sudut pandang pendekatan ekonomi, psikologi, anatomi dll (objek formal) demikianlah hal yang sama terjadi dalam dunia pendidikan hingga terjadi proses pembelajaran mengenai IPA dapat dikaji dengan pendekatan ilmu agama dan sosial, hal ini menujukan bahwasanya setiap ilmu memiliki saling keterkaitan..

\section{Konsep Penciptaan Alam Semesta dan Tata Surya menurut Persepktif Sains dan Islam}

\section{Konsep Penciptaan Alam Semesta dan Tata Surya Perspektif Sains}

Teori BIGBANG Edwin Hubble (1929). Semua benda di alam semesta pada awalnya adalah satu wujud, dan kemudian terpisah-pisah. Alam semesta telah terbentuk melalui ledakan titik tunggal bervolume nol ini.dan ledakan inilah yang disebut dengan Big Bang atau ledakan raksasa dari satu titik tunggal, dan membentuk alam semesta kini dengan cara pemisahan satu dari yang lain. (Caner taslaman. 2011).

Gerakan matahari dan bulan serta bumi berlangsung tanpa sedikit pun bersingunggan dengan kehidupan kita. Bulan berotasi pada porosnya dil luar angkasa selama waktu yang setara dengan waktu mengelilingi bumi yaitu 29,5 hari. Jadi yang kita lihat selalu bulan yang sama. Matahari berputar pada sumbunya kira-kira selama 25 hari. (Marurice Bucaille dalam Caner taslaman. 2011) Matahari berputar pada sumbunya sembari juga bergerak ke arah tertentu, bumi di lain pihak, memiliki bebebrapa pergerakan; ia berputar pada sumbunya, beredar mengelilingi matahari, bergantung pada matahari, dan juga dipengaruhi oleh bulanan. Dalam semua pergerakan cepat ini, bumi kita berubah sepanjang waktu berdasarkan posisinya terhadap sistem tata surya dan galaksi. Tidak satu pun dari 
pergerakan tersebut mempengaruhi posisi kita dalam hubungannya terhadap matahari, dan juga tidak membuat hidup kita berakhir di bumi ini. (Caner taslaman. 2011).

Copernicus, Kepler, dan Galileo mengeluarkan pendapat bahwa mataharilah yang tidak bergerak dan bumi dan bumi berputar mengelilingi matahari.belakangan, berkata teleskop canggih dan kumpulan data kosmologi, barulah disimpulkan bahwa matahari bergerak, dan bumi mengelilingi matahari yang bergerak ini. (Caner taslaman. 2011). Semua gerakan matahari, bulan, dan bumi terus berlangsung dalam keselarasan sempurna. Segala sesuatunya diatur demikian hebatnya sehingga bahkan yupiter, planet terbesar dalam tata surya menyumbang pada kehidupan bumi. Astronom Gorge Wetherill, dalam artikelnya tentang Yupiter, mengatakan bahwa jika Yupiter tidak berada di tempat yang seharusnya sekarang ini, kita tidak mungkin di sini karena bumi bisa saja hancur karna saling bertabrakan. (Caner taslaman. 2011). Unsur-unsur yang membentuk gunung adalah sama dengan unsur-unsur yang membentuk bumi yang sangat dibutuhkan oleh tumuh-tumbuhan untuk berkembang. Ketika air hujan jatuh membasahi gunung, batu-batunya hancur sedikit demi sedikit dengan ukuran dan timbangan. Lalu, air-air itu membawa bagian-bagian yang hancur agak lembut seperti tanah. Air yang mengandung endapan pasir ini menyirami tanah pertanian. Lalu, menumpuk endapan pada tanah sebagai sumber makanan manusia dan mata air bagi sungai-sungai. (Ahmad khalid. 2005).

Lempengan bumi mengembang di atas cairan. Lapisan terluar bumi tebalnya $5 \mathrm{~km}$ dari permukaan. Kedalaman strata gunung mencapai $35 \mathrm{~km}$. Karena itu, gunung layaknya pasak yang dipancangkan ke dalam bumi. Persis seperti pasak yang digunakan untuk memancangkan tenda ke tanah, amka pasak ini memancangkan lempengan-lempengan bumi. (Caner taslaman. 2011) Dunia dan matahari tidak langsung segera ada setelah ledakan besar itu (bigbang) karena alam semesta berada dalam keadaan gas sebelum pembentukan bintang. Keadaan gas ini pada awalnya terbuat dari hidrogen dan helium. Pemadatan dan pemampatan membentuk planet, bumi, matahari dan bintang yang tidak lain adalah produk gas.(Caner taslaman. 2011). Lapisan atmosfer terdiri dari lapisan-lapisan yaitu : (1). Troposfer; (2). Stratosfer; (3). Ozononosfer; (4). Mesosfer; (5). Termosfer; (6). Lonosfer; (7). Eksosfer. Setiap lapisan atsmosfer ini memiliki fungsinya masing-masing. (Caner taslaman. 2011). Bentuk bumi adalah lonjong. Bentuk lonjong tersebut sulit dipahami lalu penerjemah menerjemahkannya sebagai terhampar. (Caner taslaman. 2011).

\section{Konsep Penciptaan Alam Semesta dan Tata Surya Perspektif Islam}

Ayat yang menjelaskan tentang Penciptaan Tata Surya dan Alam Semesta. Berikut adalah ayat-ayat $\mathrm{Al}$-quran yang berkaitan dengan alam semesta dan tata surya:

Tabel 1. Tabel Teks Ayat Al-Qur'an dan Terjemahan

\begin{tabular}{|c|c|c|c|}
\hline NO & SURAT & AYAT & Terjemahan \\
\hline 1 & $\underset{21: 30}{\text { Q.S Al-Anbiya }}$ & 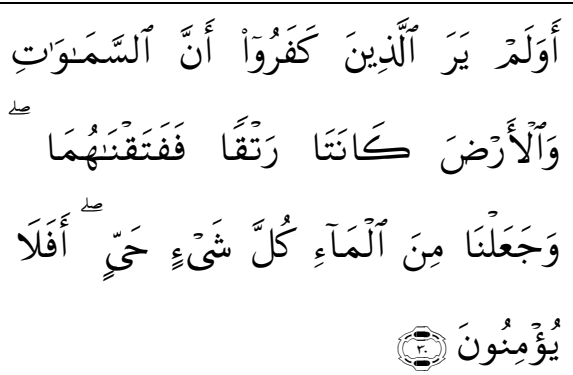 & $\begin{array}{l}\text { Dan apakah orang-orang kafir } \\
\text { tidak mengetahui bahwa langit dan } \\
\text { bumi keduanya dahulu menyatu, } \\
\text { kemudian kami pisahkan antara } \\
\text { keduanya; dan kami jadikan segala } \\
\text { sesuatu yang hidup berasal dari air, } \\
\text { maka mengapa mereka tidak } \\
\text { beriman? }\end{array}$ \\
\hline
\end{tabular}




\begin{tabular}{|c|c|c|c|}
\hline 2 & $\begin{array}{l}\text { Q.S Al-Anbiya } \\
21: 33\end{array}$ & 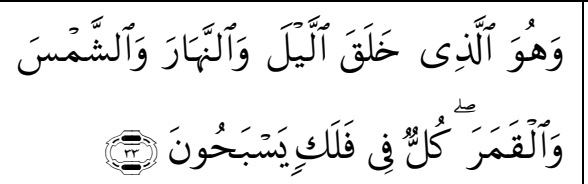 & $\begin{array}{l}\text { Dan Dialah yang telah } \\
\text { menciptakan malam dan siang, } \\
\text { matahari dan bulan. Masing-masing } \\
\text { beredar pada garis edarnya }\end{array}$ \\
\hline 3 & $\begin{array}{l}\text { Q.S Yasin : } \\
36: 40\end{array}$ & 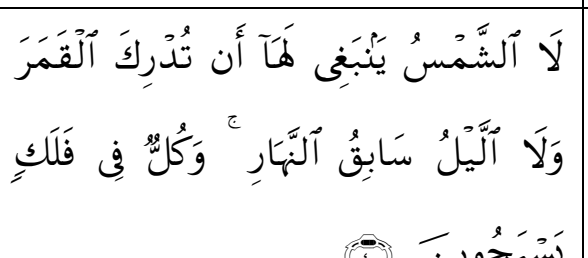 & $\begin{array}{l}\text { Tidaklah mungkin bagi matahari } \\
\text { mengejar bulan dan malam pun } \\
\text { tidak dapat mendahului siang. } \\
\text { Masing-masing beredar pada garis } \\
\text { besarnya. }\end{array}$ \\
\hline 4 & $\begin{array}{l}\text { Q.S Fussilat 41: } \\
10\end{array}$ & 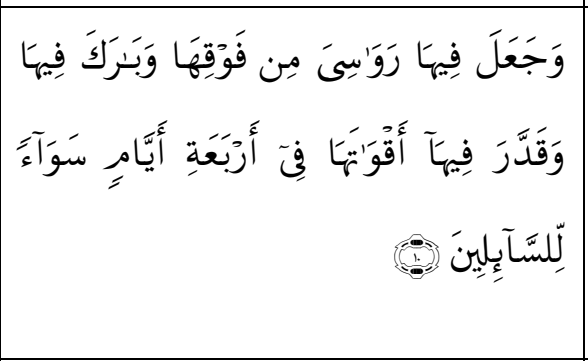 & $\begin{array}{l}\text { Dan Dia ciptakan padanya gunung- } \\
\text { gunung yang kokoh di atasnya. } \\
\text { Dan kemudian berkahi, dan Dia } \\
\text { tentukan makanan-makanan (bagi } \\
\text { penghuni)nya dalam empat masa, } \\
\text { memadai untuk (memenuhi } \\
\text { kebutuhan) mereka yang } \\
\text { memerlukannya. }\end{array}$ \\
\hline 5 & $\begin{array}{l}\text { Q.S Fussilat 41: } \\
11\end{array}$ & 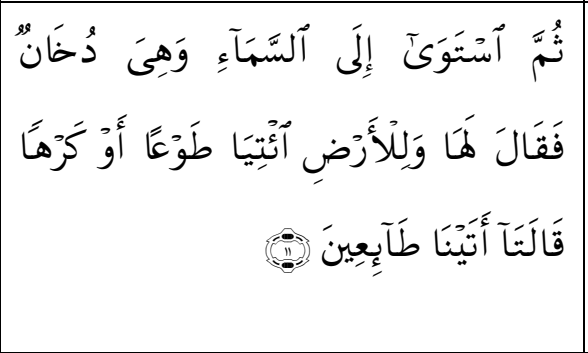 & $\begin{array}{l}\text { Kemudian Dian menuju ke langit } \\
\text { dan (langit) itu masih berupa asap, } \\
\text { lalu Dia berfirman kepadanya dan } \\
\text { kepada bumi, "datanglah kamu } \\
\text { berdua menurut perintah-Ku } \\
\text { dengan patuh atau terpaksa." } \\
\text { Keduanya menjawab. "kami datang } \\
\text { dengan patuh." }\end{array}$ \\
\hline 6 & $\begin{array}{l}\text { Q.S Fussilat 41: } \\
12\end{array}$ & 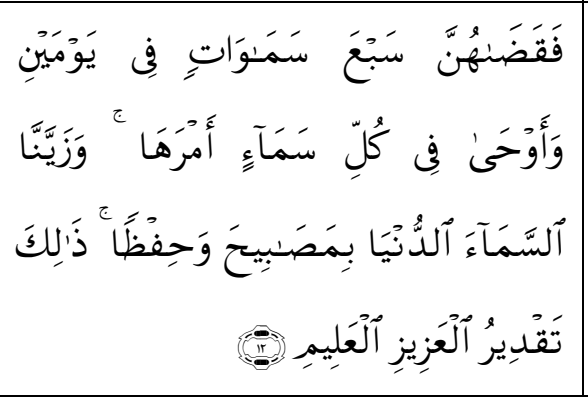 & $\begin{array}{l}\text { Lalu diciptakan-Nya tujuh langit } \\
\text { dalam dua masa pada setiap langit } \\
\text { Dia mewahyukan urusan masing- } \\
\text { masing. Kemudian langit yang } \\
\text { dekat (dengan bumi), kami hiasi } \\
\text { dengan bintang-bintang, dan (kami } \\
\text { ciptakan itu) untuk memelihara. } \\
\text { Demikianlah ketentuan Allah Yang } \\
\text { Maha Perkasa, Maha Mengetahui. }\end{array}$ \\
\hline 7 & $\begin{array}{l}\text { Q.S An-Nari'at } \\
79: 30\end{array}$ & عَدَ ذَلِكَ دَحَنْهَا & $\begin{array}{l}\text { Dan setelah itu bumi Dia } \\
\text { hamparkan }\end{array}$ \\
\hline
\end{tabular}

\section{Penafsiran Ulama}

Berikut ini adalah ayat-ayat al-quran serta penafisrannya menurut beberapa ahli tafsir yang berkaitan dengan penciptaan alam semesta dan tata surya :

Tabel 2. Tabel Penafsiran Ayat menurut Ulama

\begin{tabular}{|l|l|l|l|l|}
\hline \multirow{2}{*}{ NO } & \multirow{2}{*}{ SURAT } & \multicolumn{4}{|c|}{ TAFSIR } \\
\cline { 3 - 5 } & & \multicolumn{4}{|c|}{ I } \\
\hline 1 & $\begin{array}{l}\text { Q.S Al-Anbiya } \\
21: 30\end{array}$ & $\begin{array}{l}\text { Dulu bumi dan langit adalah satu } \\
\text { yang menempel (bersatu padu) } \\
\text { kemudian langit dipisahkan oleh }\end{array}$ & $\begin{array}{l}\text { Orang-orang kafir tidak } \\
\text { mengetahui bahwa langit dan bumi } \\
\text { keduanya dulu adalah suatu yang }\end{array}$ \\
\hline
\end{tabular}




\begin{tabular}{|c|c|c|c|}
\hline & & $\begin{array}{l}\text { awan sedangkan bumi dipidahkan } \\
\text { oleh tumbuh-tumbuhan. (tafsir } \\
\text { Fathul Qadir. Imam Muhammad bin } \\
\text { Ali bi Muhhamd Asy-Syaukani. (jil.7). } \\
\text { 2011) }\end{array}$ & $\begin{array}{l}\text { padu. Sesungguhnya Allah } \\
\text { menahan langit dan bumi supaya } \\
\text { jangan lenyap. Allah menciptakan } \\
\text { langit dan bumi sebagiannya di atas } \\
\text { sebagian lainnya, kemudian } \\
\text { menciptakan angin di tengahnya } \\
\text { sehingga membukanya } \\
\text { (memisahkannya) dengan itu. Dan } \\
\text { Allah menjadikan langit menjadi } \\
\text { tujuh dan bumi menjadi tujuh. } \\
\text { (tafsir Al-Qurtubi, Syaikh Imam. } \\
\text { (ji.11). 2015) }\end{array}$ \\
\hline 2 & $\begin{array}{l}\text { Q.S Al-Anbiya } \\
21: 33\end{array}$ & $\begin{array}{l}\text { Allah menciptakan langit dan } \\
\text { bintang-bintang seisinya yang } \\
\text { semuanya mengorbit di pintu-pintu } \\
\text { langit, sebagaimana seputarnya pada } \\
\text { alat pemintal. (tafsir Fathul Qadir. } \\
\text { Imam Muhammad bin Ali bi } \\
\text { Muhhamd Asy-Syaukani. (jil.7). } \\
\text { 2011) }\end{array}$ & $\begin{array}{l}\text { Allah menciptakan malam dan } \\
\text { siang. Masing-masing dari matahari, } \\
\text { bulan, bintang, galaksi, malam dan } \\
\text { siang beredar pada garis edarnya, } \\
\text { maksudnya adalah bergerak dan } \\
\text { berjalan cepat bagaikan berenang di } \\
\text { atas air. Garis rotasi bintang } \\
\text { matahari dan bulan berada di antara } \\
\text { langit dan bumi di mana bintang- } \\
\text { bintang bergerak secara berkeliling } \\
\text { sedangkan langit tetap. (tafsir Al- } \\
\text { Qurtubi, Syaikh Imam. (ji.11). } \\
\text { 2015) }\end{array}$ \\
\hline 3 & $\begin{array}{l}\text { Q.S Yasin } \\
\text { 36:40 }\end{array}$ & $\begin{array}{l}\text { Matahari tidak mungkin ada di } \\
\text { malam hari dan malam pun tidak } \\
\text { dapat mendahului siang. Masing- } \\
\text { masing matahari, bulan dan bintang } \\
\text { beredar pada garis edarnya, } \\
\text { maksudnya mereka selalu bergerak } \\
\text { bolak-balik terus menerus. Semua ini } \\
\text { adalah bukti nyata dan argumen yang } \\
\text { luar biasa atas keangungan sang } \\
\text { pencipta dan keagungan sifat- } \\
\text { sifatNya, terutama sifat kuasa } \\
\text { (qudrat), bikmah, dan ilmu. (tafsir al- } \\
\text { karim ar rahman (6) surat :al-fathir- } \\
\text { Qaf. syaikh abdurrahman bin nashir } \\
\text { as-sa'di. 1426 H). }\end{array}$ & $\begin{array}{l}\text { Allah menahan matahari untuk } \\
\text { tidak terbit. Dan ketika } \\
\text { dikumpulkan-Nya matahari dan } \\
\text { bulan merupakan tanda } \\
\text { berakhirnya dunia dan datangnya } \\
\text { kiamat. Matahari dan bulan serta } \\
\text { bintang-bintang beredar pada } \\
\text { masing-masing garis edarnya. (tafsir } \\
\text { al-Qurtubhi. Syaikh Imam. (jil. } \\
\text { 15).2015 }\end{array}$ \\
\hline 4 & $\begin{array}{l}\text { Q.S Fussilat 41: } \\
10\end{array}$ & $\begin{array}{l}\text { Allah membentangkan bumi dalam } \\
\text { dua hari dengan menjadikan gunung- } \\
\text { gunung di atasnya yang menjadi } \\
\text { pasang baginya agar tidak goyah, } \\
\text { tidak goncang dan agar diam. Dia } \\
\text { pun menyempurnakan penciptaan- } \\
\text { Nya dan membentangkannya serta } \\
\text { mengeluarkan makan-makannya } \\
\text { serta segala hal yang berkaitan } \\
\text { dengannya dalam empat masa, } \\
\text { sebagai jawaban bagi orang-orang } \\
\text { yang bertanya tentang hal ini. (tafsir } \\
\text { al-karim ar rahman (6) surat :al- }\end{array}$ & $\begin{array}{l}\text { Allah menciptakan bumi, bumi itu } \\
\text { bergoyang diatas permukaan air. } \\
\text { Allah berkata kepada Jibril, buat dia } \\
\text { jangan bergerak ya Jibril. Jibril turun } \\
\text { lalu memegang dengan kokoh } \\
\text { bumi, tetapi bumi tetap bergoyang } \\
\text { disebabkan angin. Jibril berkata. "ya } \\
\text { Tuhan ku, Engkau lebih } \\
\text { mengetahui, Angin lebih } \\
\text { menguasainya." Kemudian Allah } \\
\text { menciptakan gunung-gunung yang } \\
\text { seakan-akan menjadi pasak bagi } \\
\text { bumi. Dan Dia memberkahinya }\end{array}$ \\
\hline
\end{tabular}




\begin{tabular}{|c|c|c|c|}
\hline & & $\begin{array}{l}\text { fathir-Qaf. syaikh abdurrahman bin } \\
\text { nashir as-sa'di. } 1426 \mathrm{H}) \text {. }\end{array}$ & $\begin{array}{l}\text { dengan menciptkan di bumi } \\
\text { pohon-pohon. (tafsir al-Qurtubhi. } \\
\text { Syaikh Imam. (jil. 15).2015 }\end{array}$ \\
\hline 5 & $\begin{array}{l}\text { Q.S Fussilat 41: } \\
11\end{array}$ & $\begin{array}{l}\text { Kemudian setelah Dia menciptakan } \\
\text { bumi, Dia menciptakan langit. ketika } \\
\text { itu masih merupakan asap yang } \\
\text { menguap di atas permukaan air. } \\
\text { Kemudian Allah memanggil untuk } \\
\text { menjalankan perintahnya dengan } \\
\text { suka hati atau terpaksa. Keduanya } \\
\text { menjawab kami datang dengan suka } \\
\text { hati, kami tidak mempunyai } \\
\text { keinginan yang menyelisihi } \\
\text { keinginan-Mu. (tafsir al-karim ar } \\
\text { rahman (6) surat :al-fathir-Qaf. } \\
\text { syaikh abdurrahman bin nashir as- } \\
\text { sa'di. 1426 H). }\end{array}$ & $\begin{array}{l}\text { Kemudian Allah menuju pada } \\
\text { penciptaan langit dan langit itu } \\
\text { masih berupa asap kemudian Allah } \\
\text { dengan sengaja menciptakan dan } \\
\text { menyempurnakannya. Allah } \\
\text { memindahkan langit dari sifat asap } \\
\text { ke sifat ketebalannya. Asap tersebut } \\
\text { adalah uap yang keluar saat air } \\
\text { bernafas. Kemudian dia } \\
\text { berkehendak menciptakan langit } \\
\text { lalu dijadikan-Nya tujuh langit. } \\
\text { Kemudian Dia memanggil langit } \\
\text { dan bumi untuk mengikuti } \\
\text { perintahnya untuk memenuhi } \\
\text { bumi dan langit dengan beragam } \\
\text { manfaat dan kebutuhan bagi } \\
\text { makhluk-makhluk ciptan-Ku. } \\
\text { tafsir al-Qurtubhi. Syaikh Imam. } \\
\text { (jil. 15).2015 }\end{array}$ \\
\hline 6 & $\begin{array}{l}\text { Q.S Fussilat 41: } \\
12\end{array}$ & $\begin{array}{l}\text { Allah menciptakan langit menjadi } \\
\text { tujuh langit dalam dua masa. Dengan } \\
\text { demikian selesailah penciptaan langit } \\
\text { dan bumi dalam enam hari, dimulai } \\
\text { Hari Ahad dan berakhir pada hari } \\
\text { Jumat, sekalipun Allah dengan } \\
\text { kekuasaannya mampu menciptakan } \\
\text { itu sekali saja namun Ia menciptakan } \\
\text { langit dan bumi ini dalam tempo } \\
\text { yang telah ditetapkan. (tafsir al-karim } \\
\text { ar rahman (6) surat :al-fathir-Qaf. } \\
\text { syaikh abdurrahman bin nashir as- } \\
\text { sa'di. } 1426 \mathrm{H} \text { ). }\end{array}$ & $\begin{array}{l}\text { Allah menciptakan Bumi dalam dua } \\
\text { hari. Kemudian menentukan } \\
\text { bahan-bahan makanan di dalamnya } \\
\text { selama dua hari. Menciptakan langit } \\
\text { dalam dua hari. Allah menciptakan } \\
\text { bumi pada hari Minggu dan seni, } \\
\text { dan menetapkan bahan makanan } \\
\text { pada hari selasa dan rabu allah } \\
\text { menciptakan langit pada hari kamis } \\
\text { dan jumat. ( tafsir al-Qurtubhi. } \\
\text { Syaikh Imam. (jil. 15).2015 }\end{array}$ \\
\hline 7 & $\begin{array}{l}\text { Q.S An-Nari'at } \\
79: 30\end{array}$ & $\begin{array}{l}\text { Allah menghamparkan } \\
\text { (membentang) bumi di atas tanah. } \\
\text { (tafsir Fathul Qadir. Imam } \\
\text { Muhammad bin Ali bi Muhammad } \\
\text { Asy-Syaukani. (jil.12). 2011) }\end{array}$ & $\begin{array}{l}\text { Allah membenahi bumi dan } \\
\text { menghamparkannya sehingga } \\
\text { menjadi layak untuk dihuni dan } \\
\text { dijadikan tempat berjalan bagi } \\
\text { sekalian manusia dan bintang. } \\
\text { (tafsir ibnu katsir. Abul Fida Ismail } \\
\text { bin Umar bin Katsir.(jil.10). 2009). }\end{array}$ \\
\hline
\end{tabular}

\section{METODE PENELITIAN}

Metode yang digunakan penulis dalam penulisan artikel ini yaitu menggunakan metode penelitian kepustakaan (library Research). Metode penelitian kepustakaan adalah penelitian yang membatasi kegiatannya hanya pada bahan-bahan koleksi perpustakaan saja tanpa memerlukan riset lapangan. Penelitian ini bertujuan untuk mengkaji teks, buku-buku, dan naskah publikasi mengenai integrasi Islam dan Sains dalam Pokok bahasan Penciptaan Tata Surya dan Alam Semesta yang bersumber dari naskah-naskah kepustakaan relevan yang diangkat sebagai permasalahan dalam topik penelitian ini. Penelitian ini menggunakan 
desain kajian literatur yang bertujuan untuk mendapatkan informasi dan mengintegrasikan ilmu sains dan islam. Langkah-langkah yang dilakukan diantaranya pengumpulan data pustaka, membaca dan mencatat, serta membandingkan literatur untuk kemudian diolah dan menghasilkan kesimpulan. Data yang digunakan merupakan data sekunder yang berasal dari textbook, jurnal, artikel ilmiah, literatur review yang berisikan tentang konsep yang diteliti.

\section{HASIL DAN PEMBAHASAN}

Temuan dalam penelitian ini berdasarkan dari konteks Al-Quran dan Sains mengenai Proses penciptaan Alam Semesta dan Tata Surya, di mana antara keduanya terjadi integrasi dan ditemukan benang merah terkait bagaimana alam semesta beserta isinya terjadi. Adapun penjelasan sebagai berikut:

\section{Penciptaan Bumi}

\section{Awal Penciptaan Bumi}

Awal penciptaan bumi dengan segala isinya terjadi dalam enam periode, dan setiap periodenya belum diketahui berapa ribu tahun. Menurut ahli astronomi, berdasarkan ayat An-Naziat: 27-33 memberikan petunjuk tentang penciptaan alam semesta dengan peristiwa Big Bang, yaitu ledakan besar sebagai awal lahirnya ruang dan waktu, termasuk materi. Kemudian pada ayat ke 28 yang memberi petunjuk pengembangan alam semesta, sehingga benda-benda langit makin berjauhan (dalam bahasa awam berarti langit makin tinggi). Hal ini memberikan pengertian bahwa pembentukan benda langit bukanlah proses sekali jadi, tetapi proses evolutif (perubahan bertahap). Pada ayat ke 30 menjelaskan proses evolusi di bumi, setelah bulan terbentuk dari lontaran sebagian kulit bumi karena tumbukan benda langit lainnya, dan bumi dihamparkan mungkin saat lempeng benua besar pangea mulai terpecah tetapi bisa jadi lebih tua dari pangea. (LIPI, 2010: 21-25)

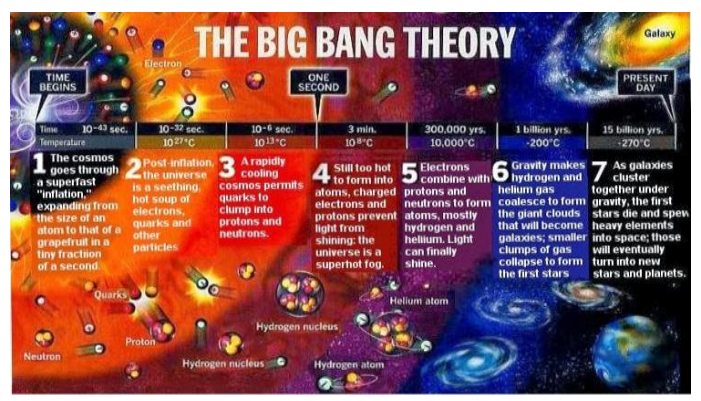

Gambar 1. Teori Big Bang

\section{Anatomi Bumi}

Anatomi bumi mencakup bahasan tentang bentuk, ukuran, dan struktur bumi. Allah tidak menerangkan secara jelas dalam Al-Qur'an sebab hal ini dapat di teliti mandiri oleh manusia. ayat 22 surah al-baqarah menerangkan bahwa Allah membuat bumi sebagai hamparan yang luas tempat kehidupan manusia dan berbagai makhluknya dengan langit sebagai atapnya. Bumi merupakan hamparan luas, karena meski bentuknya mendekati bundar seperti bola, tetapi karena sangat besar dibanding ukuran manusia, maka 
permukaannya tampak dasar dan luas terhampar. (LIPI, 2010: 32-35). Ayat 5 surah azZumar memberi isyarat tentang sifat bumi, bentuk sekaligus gerakannya. Ayat ini menjelaskan siang ditutupkan atas malam dan malam atas siang, artinya ada proses yang sifatnya gradual, sedikit demi sedikit. Hal ini dapat di jelaskan bahwa bentuk bumi adalah bulat seperti bola dan berotasi di hadapan matahari. Dengan demikian bagian yang menghadap matahari merupakan daerah siang dan bagian yang membelakangi matahari daerah malam.

Menurut beberapa ahli, dengan memperhatikan keadaan bumi dan mencoba mengukurnya, diperoleh gambaran bahwa bumi ini tidak bundar betul, tetapi pepat pada bagian kutub-kutubnya. Jari-jari bumi rata-rata sekitar $6.371 \mathrm{~km}$, sedangkan jari-jari bumi ekuartil sekitar $6.378 \mathrm{Km}$. Adapun luas permukaan bumi sekitar 510 juta $\mathrm{km} 2$ di mana $71 \%$ berupa lautan dan 29\% berupa daratan (Wylie, 1971). Bumi memiliki sifat-sifat fisis, antara lain memiliki medan magnetik, medan gaya berat (gravity), medan elektromagnetik, dan dapat menghantarkan gelombang-gelombang elastik.

Allah menciptakan bumi dalam tujuh lapisan, namun $\mathrm{Al}$ quran tidak menjelaskan secara rinci apa saja komponen yang terdapat dalam tia lapisan. Beberapa ahli geologi mengatakan bahwa kalau ditelaah, struktur bumi dapat dibayangkan seperti bawang, hanya saja, bumi bentuknya mendekati bundar. Bumi terdiri dari satu seri lapis-lapisan bola (concentric shell), secara berurutan dari bagian paling dalam, lapisan bumi terdiri dari: inti bumi bagian dalam (inner core), inti bumi bagian luar (outer care)mantel bumi bagian dalam (inner mantel), mantel bumi bagian luar (upper mantel), astenosfer, fitosfer, dan kerak bumi. (LIPI, 2010:38)

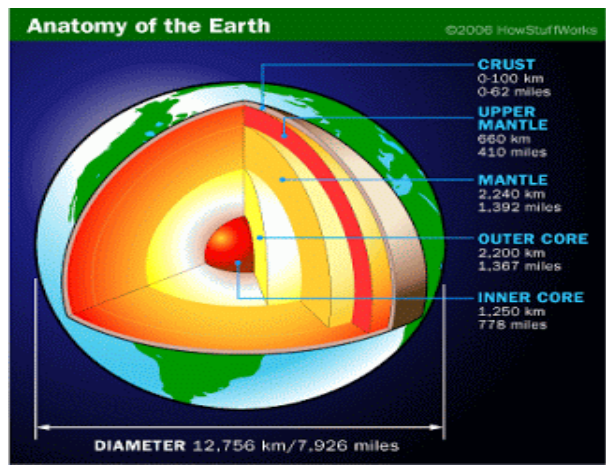

Gambar 2.Anatomi Bumi

\section{Penciptaan Bumi dalam Dua Masa}

Penciptaan Bumi berlangsung dalam waktu dua masa. Penciptaan Bumi terjadi dalam dua masa yaitu masa ketiga dan keempat. Pada masa ketiga adalah masa penciptaan matahari dan bumi serta planet-planet lainnya, bumi terbentuk semula oleh sekumpulan gas (could of gas) dan debu, lebih dari 4,5-4,6 miliar tahun yang lalu. Elemen-elemen ringan termasuk hidrogen $(\mathrm{H})$ dan Oksigen $(\mathrm{O})$ yang jumlahnya sangat besar terkumpul dalam planet sebagai gas yang terkondensasi dan membentuk bantuan yang lunak (molten rock) dan mulailah sejarah bumi dan planet-planet lainnya. Material-mateial yang ada kemudian terpisah berdasarkan berat jenisnya, material-material berat memisahkan diri dan menampati tempat yang dalam, sedangkan material ringan naik ke atas. Pada masa ini, yang disebut dalam geologi sebagai Hedreon eon (masa Hadean), bumi masih pada awal penciptaannya dan belum terbentuk batuan, kecuali meteorit. (LIPI, 2010: 8-9) 
Pada masa keempat adalah terjadinya proses evolusi pada planet bumi (bumi mengelilingi matahari), dan terbentuknya bulan dari lontaran sebagian kulit bumi yang selanjutnya berputar mengelilingi bumi. Pada masa keempat ini ditandai dengan bumi dihamparkan bukan pagea, tetapi "benua" dengan umur jauh lebih tua. Masa ini sesuai dengan penemuan umur batuan tertua pada masa Arkean. (link vidio : https://www.youtube.com/watch?v=T6iTFrtoLQo )

\section{Penciptaan Isi Bumi dalam Dua Masa}

Allah menciptakan bumi dan segala isinya. Penciptaan Isi bumi terjadi dalam dua masa yaitu pada masa ke lima dan keenam. Masa kelima ditandai oleh penciptaan kehidupan dan air, di duga masa ini berlanjut setelah bumi dihamparkan. Pada masa ini ditandai dengan ketersediaan air, masa kelima ini dalam geologi mungkin pararel dengan masa proterozoikum di mana dijumpai, meski dalam jumlah yang tidak banyak, binatangbinatang dalam bentuk primitif.

Pada masa keenam merupakan masa pembentukan penggununggan. Pada masa ini pembentukan gunung terjadi di wilayah interaksi dua lempeng. Pada masa ini pula terjadi peristiwa hebat yakni musnahnya dinosaurus serta yang paling penting adalah munculnya manusia batuan. Pembentukan gunung mengikutsertakan proses pengangkatan batuanbatuan yang terbentuk sebelumnya dan proses magmatik yang bisa jadi disertai mineralisasi yang memungkinkan terbentuknya mineral logam seperti $\mathrm{Zn}$ (seng), $\mathrm{Cu}$ (Tembaga), Ph (timah hitam), Au (Emas) dan lain sebaginya yang angat bermanfaat bagi kehidupan manusia.(LIPI, 2010: 10-11).

Gunung-gunung juga dapat menahan awan yang mengandung hujan, sehingga berkumpul dan bertindih-tindih, kemudian menjadi hujan. Gunung-gunung yang telah terangkat tidak terlepas dari pelapukan dan erosi. Hujan lambat laun menggerus gununggunung yang terbentuk itu juga mengandung mineral yang bermanfaat. Gunung-gunung, tetumbuhan dan pepohonan menjadi media yang memproses terjadinya makanan bagi manusia dan seluruh makhluk yang ada di bumi, hal ini terjadi setelah empat masa.

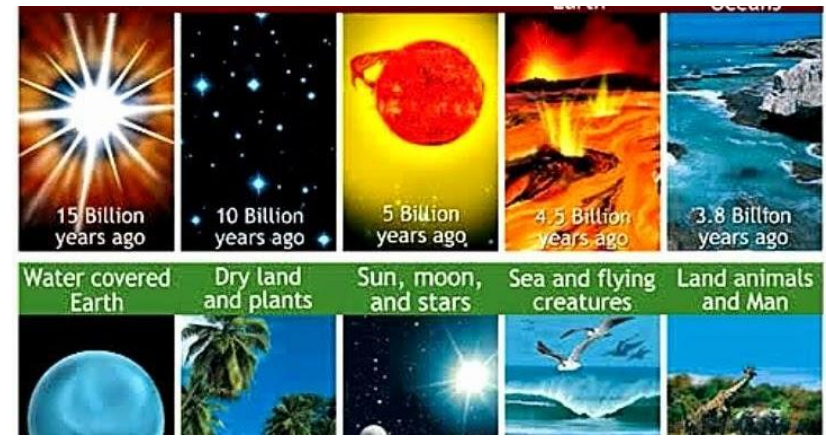

Gambar 3. Pembagian masa Penciptaan Alam semesta

\section{Penciptaan Langit}

Penciptaan bumi telah selesai, kemudian Allah menciptakan langit. Ketika itu langit masih merupakan asap yang menguap di atas permukaan air (fussilat:11). Allah menciptakan bumi dengan segala isi dan berbagai manfaatnya. Demikian dengan langit Allah menciptakan tujuh lapisan dengan berbagai macam manfaatnya pula (al-baqarah: 29). Allah menciptakan langit menjadi tujuh langit dalam dua masa yaitu pada hari kamis dan jumat (fussilat: 12). Kemudian dalam surat Al-Anbiya: 32-33 Allah menciptakan langit dan 
bintang-bintang sebagai atap yang terpelihara. Allah menciptakan langit dan bintangbintang seisinya yang semuanya mengorbit di pintu-pintu langit, sebagaimana seputarannya pada alat pemintal. (Carner, 2006: 38).

Secara sains mengenai penciptaan langit, dunia dan matahari tidak langsung segera ada setelah ledakan besar itu (bigbang) karena alam semesta berada dalam keadaan gas sebelum pembentukan bintang. Keadaan gas ini pada awalnya terbuat dari hidrogen dan helium. Pemadatan dan pemampatan membentuk planet, bumi, matahari dan bintang yang tidak lain adalah produk gas. Atmosfer adalah selimut gas tak kasatmata setebal $10.000 \mathrm{~km}$ yang melingkupi planet kita. Walaupun strukturnya transparan, atmosfer merupakan perisai baja. Kalau tidak karena keistimewaan ini, tidak akan ada kehidupan di bumi, dan bumi akan berlubang-lubang, atmosfer juga berfungsi menyaring sinar berbahaya matahari, melindungi kehidupan bumi dari kepunahan. Rancangan menakjubkan ini juga sebagian radiasi elektromagnetik. Jadi atmosfer menyaring sinar-sinar berbahaya dan meneruskan sinar-sinar yang diperlukan untuk kehidupan. Penyusutan yang dapat dilihat pada atap dari lapisan-lapisan khusus berkaitan dengan pemeliharaan bumi. Yaitu, yang dinamakan lapisan gas pada bumi. Lapisan ini menyusut pada malam hari dan membesar pada siang hari. Lapisan-lapisan meninggi pada malam hari untuk membiarkan sinar-sinar alam menembus ke lapis-lapisan bawah dari kover gas. (Carner, 2006: 44).

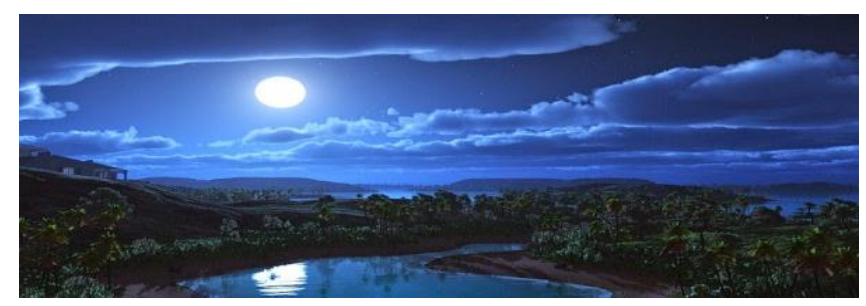

Gambar 4. langit dilihat dari permukaan bumi

\section{Penciptaan Tujuh Langit dalam Dua Masa}

Penciptaan tujuh langit itu terjadi dalam dua masa. Allah memberikan informasi dalam surat Fussilat: 12. Ayat ini menerangkan bahwa Allah menyempurnakan kejadian langit dengan menjadikannya tujuh lapis dalam dua masa. Masa yang maksud, adalah dua periode yang rentang waktunya sangat panjang. Pada awalnya, Allah menciptakan langit pertama, dan kemudian disempurnakan menjadi tujuh langit yang berlapis-lapis. Selanjutnya dijelaskan bahwa setiap langit memiliki fungsi dan keadaan yang berbeda. Masing-masing langit mempunyai kegunaan yang berbeda untuk kepentingan makhluk yang ada di bawahnya, misalnya langit yang berfungsi memperkuat gaya tarik planet-planet, sehingga benda-benda tetap bergerak pada orbitnya, tidak oleng, atau menyimpang yang mungkin bisa menyebabkan tabrakan antara satu dengan yang lain (LIPI, 2010:3-7).Secara sains penciptaan lapisan-lapisan yang serasi ini adalah fenomena yang bisa di lihat dari atom yang mikrokosmos sampai pada alam semesta yang mikrokosmos. Lapisan-lapisan orbit elektron yang mengelilingi inti atom. Fakta bahwa jumlah maksimal orbit di atom adalah tujuh. Lapisan-lapisan atmosfer juga terdiri dari tujuh. Lapisan atmosfer terdiri dari lapisanlapisan yaitu : (1). Troposfer; (2). Stratosfer; (3). Ozononosfer; (4). Mesosfer; (5). Termosfer; (6). Lonosfer; (7). Eksosfer. Setiap lapisan atmosfer ini memiliki fungsinya masing-masing. 


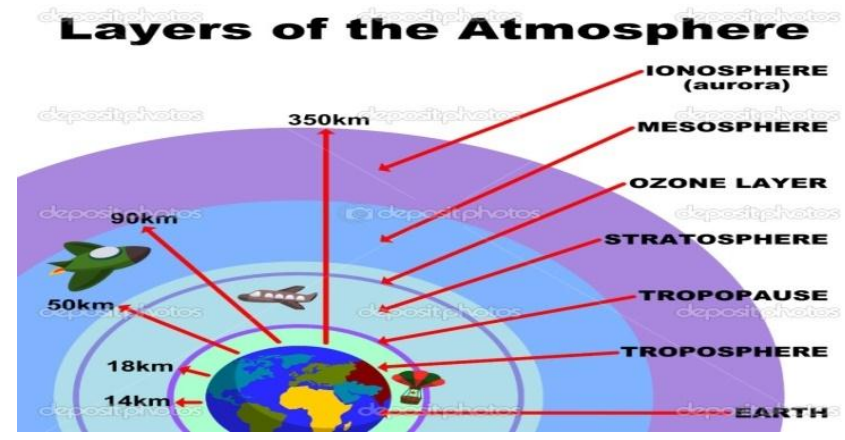

Gambar 5. Tujuh Lapisan Atmosfer

\section{Hakikat Tujuh Langit}

Ayat 10 surat Lukman mengatakan bahwa Alllah menciptakan tujuh langit secara bertingkat-tingkat tiap benda alam itu seakan terapung kokoh di tengah-tengah jagat raya tanpa da tiang yang menyangga dan tanpa ada tali yang mengaitnya. Kajian astronomis memahami tujuh langit berkaitan dengan planet, benda-benda ruang angkasa dan juga lapisan atmosfer yang terdiri dari tujuh lapisan. Hakikat tujuh langit bisa dimaknai jumlah benda langit yang sangat banyak sekali, seperti yang dipahami dalam astronomi. Perlu diperhatikan bahwa Al-Quran menyebutkan bahwa tujuh langit itu di cipta dalam keadaan bertingkat-tingkat (lihat surah al-mulk:3 dan nuh:15). Ungkapan ini tidak harus di maknai bahwa benda-benda langit itu berada pada jarak yang berbeda-beda, sehingga dapat disebut bertingkat-tingkat, ada di antara langit itu yang jaraknya dekat dan ada pula yang jauh. Langit juga dapat dimaknai sebagi segala sesuatu yang ada di atas kita dengan demikian kata langit dapat mencakup dari atmosfer yang melingkupi bumi sampai galaksi yang terjauh. (LIPI, 2010: 49-56)

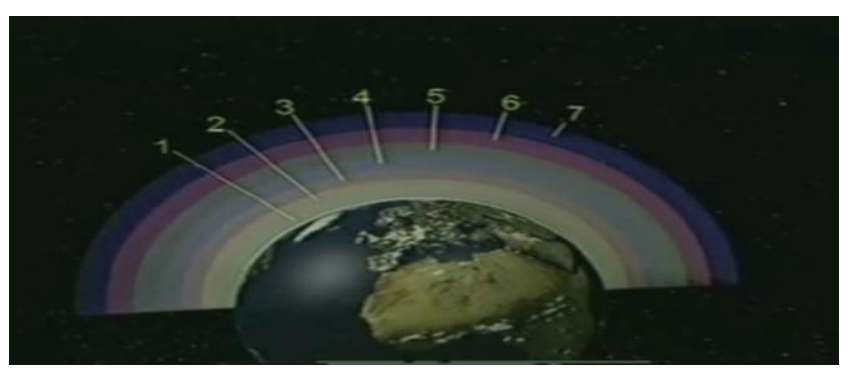

Gambar 6. tujuh lapisan langit

\section{Struktur Alam Semesta}

Dalam surat ar-Ra'ad: 2 menjelaskan penciptaan sesuatu secara terstruktur dengan baik. Rincian di uraikan dalam penciptaan adalah dengan menerangkan hal-hal apa saja yang merupakan kelanjutan dari penciptaan yang disebut. Artinya, penciptaan sesuatu akan dilanjutkan dengan penciptaan- benda-benda terkait dengan benda tersebut. Ketika menjelaskan masalah yang berkaitan dengan langit, Allah menerangkan bagaimana langit ditinggikan tanpa tiang seperti yang terlihat. Alam semesta dicipta menyerupai bentuk sebuah bola besar, yang dindingnya menyatu dengan tiang yang saling bertemu antara dasar, dinding, dan atap atau langitnya. Temuan ilmiah menyatakan teknologi bangunan seperti bola inilah yang menyebabkan suatu konstruksi tidak lagi memerlukan tiang.

Benda-benda langit merupakan bagian dari ciptaan-Nya. Allah menjelaskan bagaimana Dia menundukkan matahari dan bulan dalam arti menetapkan keadaannya yang meliputi fungsi, gerak rotasi dan revolusinya (gerak pada poros dan pada orbitnya) yang 
terus berlaku sesuai dengan ketetapan waktu yang telah ditentukan. Ketika menjelaskan keadaan matahari yang bersinar, Allah juga menerangkan bagaimana sinar matahari memberikan pengaruh pada alam raya, yaitu dengan terjadinya malam dan siang. Fenomena ini merupakan akibat logis dari pergerakan benda-benda angkasa pada porosnya. Seperti bumi yang juga berotasi, gerakan perputaran tersebutlah yang menyebabkan sebagian wilayah menghadap matahari dan mendapat sinar sehingga menjadi terang. Inilah munculnya malah dan siang (dalam surat Ibrahim:33). Allah menjelaskan hakikat matahari dan bulan bahwa sesungguhnya matahari yang memiliki cahaya, sedangkan bulan tidak.(LIPI, 2010:57). Setelah menciptakan bumi yang dihamparkan bagi makhluk-Nya dan langit yang di atas sebagai atap, Allah kemudian menjelaskan penciptaan hujan yang diturunkan dari langit dan manfaatnya; yaitu, untuk menyuburkan bumi sehingga bagian ini dapat menumbuhkan tanaman dan buah-buahan yang bermanfaat sebagai makanan bagi semua yang hidup di atasnya struktur demikian merupakan grand desing dari perencanaan yang ditetapkan Allah. (LIPI, 2010:59)

Dengan hanya mengandalkan pengamatan, kita tidak mungkin menggambarkan bagaimana wujud alam semesta ini. Maka diperlukanlah suatu model matematis yang dapat menjelaskan "bentuk" alam semesta ini termasuk evolusinya. Dengan menggunakan solusi kosmologis persamaan Einstein dan prinsip kosmolologis yang menggap bahwa alam semesta homogen di mana pun dan isotropik di setiap titik di alam, di dapatkan dua model alam semesta: "terbuka" (atau tak berhingga) dan "tertutup" (atau berhingga tak terbatas). Prinsip kosmologis yang diasumsikan tersebut didasarkan hasil pengamatan bahwa alam semesta tampaknya homogen dan isotropik, yaitu galaksi-galaksi tampak tersebar seragam ke segala arah.

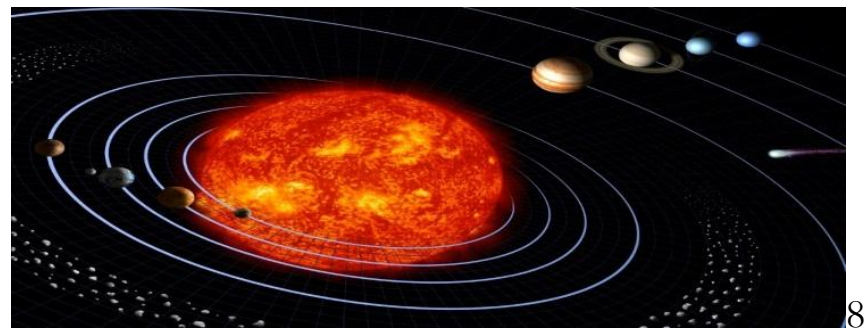

Gambar 7. Bentuk Alam semesta

\section{Kesempurnaan Ciptaan Allah \\ Benda-Benda Langit Ciptaan Allah}

Semua yang ada di alam ray ini tidak terjadi dengan sedirinya. Apa saja yang terdapat di antara langit dan bumi, baik yang dapat di indera maupun yang tidak, semuanya merupakan ciptaan Allah. Dalam surat al-Ahqaf:3 kata as-samawdt merupakan bentuk jamak dari as-sama, yang artinya langit, yang tampak dalam pandangan manusia berwarna biru. Ketika disebut dalam bentuk jamak, ini mengisyaratkan bahwa langit tidak hanya satu, tetapi banyak. Ada pula yang mengartikan langit sebagai lapisan atmosfer yang melingkupi bumi, selain itu ada pula yang memakainya dengan benda yang ada di ruang angkasa, seperti bintang dan planet. Ketika disebut dengan bentuk jamak maka yang dimaksud adalah seluruh benda langit yang ada di ruang angkasa. Termasuk dalam kategori ini adalah semua planet, bintang-bintang, dan galaksi yang ada di alam raya. Jumlah benda-benda langit yang demikian banyak ini diisyaratkan dengan sebutan es-samdwadt. Karena langit mencakup benda-benda angkasa, maka antara yang satu dengan lainnya tidak menempel; masingmasing dipisahkan oleh jarak tertentu.( LIPI, 2010: 3) 
Dalam surat al-Mulk:3 misalnya, Allah menyatakan bahwa satu langit berada di atas langit yang lain, dalam artian bahwa benda-benda langit itu berbeda-beda jaraknya. Pada ayat tersebutlah Allah menegaskan bahwa Dia-lah yang menciptakan langit dan bumi serta semua yang ada di antara keduanya. Di samping pernyataan tersebut, ayat tersebut juga memberikan dua informasi penting lainnya yaitu: (a). Bahwa penciptaan itu dilakukan dengan haq atau sebenarnya dan tujuan tertentu; dan (2). Bahwa penciptaan itu ditetapkan batas akhirnya. Allah menyampaikan bahwa keberadaan langit, bumi dan semua isinya telah ditentukan masanya, hal ini mengandung tujuan agar manusia mengetahui bahwa segala sesuatu ada batas akhirnya, demikian juga dengan keberadaan manusia itu sendiri. (LIPI, 2010:4)

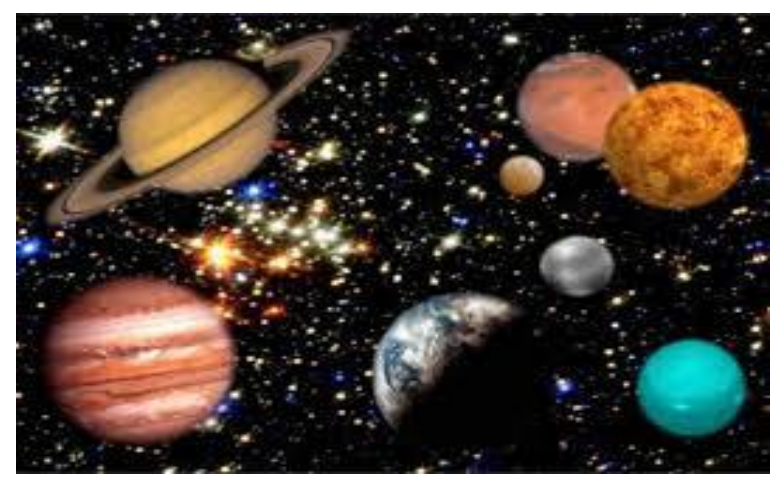

Gambar 8.benda Langit

\section{Benda-benda Langit pasti ada Fungsinya}

Penciptaan langit, bumi, dan fenomena alam lainnya pasti ada fungsi dan manfaatnya. Tanda-tanda kekuasaan Allah hanya dapat dipahami oleh orang-orang yang berakal, yaitu orang-orang yang dalam Al-Qur'an disebut sebagai ulul-albab. Penciptaan langit dan bumi dilakukan oleh Allah. Allah menganjurkan manusia untuk memikirkan fenomena alam yang terpampang, yaitu pergantian malam dan siang, mencoba mencari manfaat seperti apa yang dapat dipetik darinya dan bagaimana bersikap dalam menghadapi semua yang terjadi. Semua yang dihadapi itu sesungguhnya merupakan hukum alam dan salah satu tanda kekuasaan dan kebesaran Allah. Kajian mendalam tentang fenomena alam dan penciptaannya akan bermuara pada kesimpulan bahwa semua yang ada diciptakan tidak tanpa manfaat. Semua terwujud dengan manfaat dan faedah bagi manusia.( LIPI, 2010: 5-7)

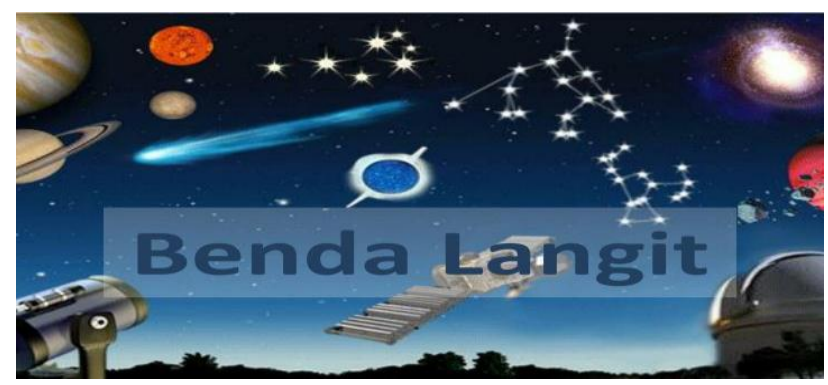

Gambar 9. Benda Langit

\section{Penciptaan yang Sempurna}

Allah Mahakuasa. Dia berkuasa atas apa saja dan berkuasa melakukan apa saja. Dalam surat al-jasiyah:3 diungkapkan tanda kekuasaan Allah yaitu penciptaan langit dan bumi. Dalam ayat tersebut menerangkan bahwa langit yang sangat luas dan di bumi tempat kediaman manusia terdapat tanda-tanda kekuasaan Allah. Tanda-tanda itu meliputi 
beragamnya benda-benda angkasa, bermacamnya makhluk yang ada di bumi, dan juga keunikan manusia secara jasmani maupun rohani. Tanda-tanda kekuasaan Allah tersebar baik dilangi, bumi, maupun di antara keduanya.

Surat ar-Rad:3 menjelaskan keberadaan dan kekuasaan Allah yang dibuktikan dengan berbagai ciptaan yang dapat dilihat dan dirasakan manusia. secara terperinci Allah menerangkan keadaan langit yang ditinggikan tanpa tiang, perjalanan matahari dan bulan yang masing-masing beredar menurut waktu dan orbit yang sudah ditentukan. Semua itu menunjukkan bahwa hanya Zat yang Mahakuasa saja yang dapat mewujudkannya. Dialah Allah Yang Mahabesar. Tanda-tanda kekuasaan Allah di langit dipaparkan dalam ayat ini sebagi berikut: (1) Penciptaan Langit di atas bumi tanpa tiang, sebagaimana yang dapat disaksikan oleh seluruh makhluk. (2) Bersemayamnya Allah di atas Arasy dan pengaturan alam semesta secara bijaksana, sehingga planet-planet dan bintang-bintang yang berjumlah miliaran tidak berbenturan antara satu dengan yang lain. Dia mengatur semua itu dengan keteraturan yang luar biasa menakjubkan.(LIPI, 2010:12).

Surat yunus:3 menjelaskan bahwa Allah menundukkan matahari dan bulan untuk matahari dan bulan untuk memberikan kemanfaatan bagi manusia dan makhluk lainnya. Masing-masing beredar dalam orbit dan waktu yang telah ditetapkan. Dengan perjalanan yang telah digariskan itu, banyak faedah yang dapat ditemukan manusia. di antara manfaat dari peredaran itu adalah menjadi patokan bagi penetapan waktu dan perhitungan tahun. Dalam surat fattr:41 dijelaskan bahwa Allah menahan langit dan bumi agar tidak lenyap. Maksudnya, Allah memelihara dan mengatur keduanya dengan kekuasaan-Nya sehingga keduanya tetap ada dan tidak hancur karena saling bertabrakan. Pemeliharaan Allah itu dilakukan dengan hukum-hukumnya, antara lain hukum gravitasi yang mengatur orbit benda-benda langit . gaya yang mengikat benda-benda langit tersebut membuat posisi setiap benda tersebut kokoh sehingga masing-masing tetap berada pada orbitnya. Setiap bintang dan planet itu bergerak porosnya dan beredar pada orbitnya masing-masing sehingga tidak saling bertabrakan, kecuali dalam kondisi tertentu. Semua itu merupakan kesempurnaan ciptaan Allah yang tak mampu dilakukan oleh manusia (LIPI, 2010, 13).

Integrasi merupakan sebuah keharusan. Integrasi dapat diterapkan di dalam pelajaran IPA, dengan mengaitkan antara Sains dan Islam maka dapat ditarik benang merah mengenai suatu kajian ilmu yang luar biasa. Mengintegrasikan pokok bahasan penciptaan tata surya dan alam semesta dilakukan untuk melihat bagaimana jika sains dan Islam disatukan dalam sebuah pembelajaran, lebih tepatnya pembelajaran mengenai penciptaan tata surya dan alam semesta di madrasah ibtidaiyah.

Penciptaan alam semesta ini diciptakan oleh Allah SWT Zat Yang Mahakuasa menciptakan langit dan bumi beserta isi dan manfaatnya dengan sempurna. Semua telah di ceritakan dalam Alquran 1400 tahun yang lalu. Secara sains dengan kontroversi para ilmuwan muncullah salah satu teori Big Bang teori yang menjelaskan bagaimana alam semesta ini terbentuk. Berdasarkan teori Big Bang yang di kemukakan oleh Hubble (1929) dalam Carner, 2006: 38). Ia mengatakan bahwa alam semesta ini awalnya satu kesatuan dan terjadi sebuah ledakan hingga partikel tersebut terpisah-pisah. Hal ini sejalan dengan yang dijelaskan dalam Al-Quran pada surat an-Anbiya:30 di katakan bahwa bumi dan langit dahulu adalah satu kesatuan yang menempel atau satu yang padu, kemudian Allah ciptakan angin di tengahnya sehingga memisahkannya dengan itu.

Alam semesta terdiri dari bumi dan langit. Di dalam Al-Quran disampaikan bahwa Allah menciptakan alam semesta ini dalam enam masa. Secara sains enam masa ini dikaitkan dengan enak periode yang jangak waktunya sangat lama. Enam masa sendiri terdiri dari dua masa Allah menciptakan Langit, Empat masa Allah ciptakan bumi dan isinya. Secara terperinci enam masa itu sebagai berikut: masa pertama, terjadinya ledakan 
Big Bang sebagai awal lahirnya ruang dan waktu. Masa kedua, terjadinya alam semesta yang mengembang, benda langit berjauhan (langit makin tinggi). Masa ketiga, masa Allah menciptakan matahari yang bersinar dan bumi yang berotasi, sehingga terjadilah siang dan malam. Masa keempat, ditandai dengan oleh penghamparan bumi dan terbentuknya bulan dari lontaran sebagian kulit bumi. Masa kelima, ditandai oleh penciptaan kehidupan dan air. Masa keenam, masa di mana Allah membentuk penggunungan.

Bumi tercipta dalam dua masa yaitu masa ketiga dan keempat. Pada masa ketiga adalah masa penciptaan matahari dan bumi serta planet-planet lainnya, bumi terbentuk semula oleh sekumpulan gas (could of gas) dan debu, lebih dari 4,5-4,6 miliar tahun yang lalu. Elemen-elemen ringan termasuk hidrogen $(\mathrm{H})$ dan Oksigen $(\mathrm{O})$ yang jumlahnya sangat besar terkumpul dalam planet sebagai gas yang terkondensasi dan membentuk bantuan yang lunak (molten rock) dan mulailah sejarah bumi dan planet-planet lainnya (LIPI, 2010:26). Pada awalnya bumi belum berbentuk bebatuan kecuali meteorit. Pada masa keempat inilah evolusi di bumi terjadi, setelah terbentuknya bulan dari sebagian lontaran kulit bumi karena tumbukan benda langit lainnya, lempeng benua besar dihamparkan yang menjadikan benua-benua mulai terpisah membentuk 5 benua plus Antartika.

Setelah Allah ciptakan bumi, Allah mengisi bumi dan manfaatnya selama dua masa pula. Yaitu pada masa kelima dan keenam. Pada masa kelima inilah Allah menciptakan sumber mata air, dari sumber mata air inilah Allah menumbuhkan tumbuh-tumbuhan guna persiapan untuk kehidupan makhluk-Nya. Kemudian di masa yang keenam Allah ciptakan gunung sebagai pasak bumi agak bumi tidak goyah dan dipacangkan gunung tersebut dengan kokoh, setlah itu baru diciptakanlah hewan dan manusia. Setelah selesai dengan penciptaan bumi dan isinya, Allah menciptakan langit yang kemudian disempurnakan menjadi tujuh langit. Masing-masing langit telah ditetapkan keadaan dan fungsinya (surat Al-Baqarah: 29). Allah juga menghiasi langit dengan bintang-bintang, planet, galaksi, meteor dan lain sebaginya. Penciptaan langit juga membutuhkan waktu dua masa. Awalnya langit terbentuk dari gas yang terbuat dari hidrogen dan helium. Pemadatan dan pemampatan membentuk planet, bumi, matahari dan bintang yang tidak lain adalah produk gas. Atmosfer adalah selimut gas tak kasatmata setebal $10.000 \mathrm{~km}$ yang melingkupi planet kita. Walaupun strukturnya transparan, atmosfer merupakan perisai baja. Atmosfer ini lah yang di sebut secara sains sebagai tujuh lapisan langit. Hakikat tujuh langit sendiri banyak ditafsirkan oleh ahli tafsir maupun sains berkaitan dengan benda benda astronomi seperti lapisan atmosfer, planet dan bintang-bintang.

Alam semesta dicipta menyerupai bentuk sebuah bola besar, yang dindingnya menyatu dengan tiang yang saling bertemu antara dasar, dinding, dan atap atau langitnya. Temuan ilmiah menyatakan teknologi bangunan seperti bola inilah yang menyebabkan suatu konstruksi tidak lagi memerlukan tiang. Inilah mengapa langit yang luas dijadikan sebagai atap bumi dan tak jatuh ke bawah. Setelah mencitakan langit Allah menghiasi langit dengan benda-benda langit seperti bulan, matahari, bintang. Semua Allah ciptakan dengan manfaatnya masing-masing. Pergerakan bulan dan matahari yang tetap berorientasi pada orbitnya bermanfaat untuk menentukan hari dan tahun. Adanya bulan dan matahari menentukan waktu siang dan malam, adanya bintang untuk membaca rasi bintang.

Sungguh keajaiban luar biasa ciptaan Allah yang diciptakan dalam enam masa, mengenai enam masa ini memunculkan pertanyaan. Apakah bumi atau langit duluan yang diciptakan? Mengenai awal penciptaan ini, sebagian mufasir ada yang mengkompromikan isi AlQur'an . menurut mereka, Allah lebih dahulu mendesain bumi dan segala isinya. Hal ini karena bumi merupakan planet utama yang akan menjadi tempat tinggal sebagian makhlukNya. Akan tetapi, dalam pelaksanaan penciptaann, Allah lebih dahulu menciptakan langit (seperti yang banyak ditemukan dalam ayat-ayat AlQuran dengan egala isinya, baru 
kemudian bumi dengan segala kelengkapannya. (Badan litbang,Lajnah Pentasihan Mushaf Qur'an, \& LIPI. 2010: 19)

Semua yang Allah ciptakan merupakan suatu bentuk kekuasaan dan kesempurnaan Allah, dengan tingkat ketelitian yang sangat tinggi yang tak tertandingi oleh manusia Allah mengontrol dan menjaga alam ini dengan sebaik baiknya. Lalu masih ada juga umat yang tidak mempercayai dengan kekuasaan Allah tersebut. Maka itulah Allah berikan manusia akal, agar mampu mencari tahu dan berpikir mengenai penciptaan Allah. Inilah salah satu alasan mengapa Allah izinkan oleh yang tidak mempercayai-Nya untuk menemukan keajaiban penciptaan-Nya, agar mereka menyadari sehingga mempercayai dan menyakini bahwa Allah-lah satu-satunya pencipta dan pemilik alam semesta beserta isinya.

Implikasi pada diri kita adalah Allah Maha Besar dengan segala kekuasaan-Nya. Ia mampu menciptakan segalanya. Jika kita kaitkan pada teori-teori yang di kemukakan ilmuwan, perlu waktu lama para ilmuwan menemukan penemuan ini, sementara Al-Quran telah menceritakannya sejak 1400 tahun yang lalu. Kita menyaksikan kesempurnaan jalannya teori-teori yang di kemukakan ilmuwan yang dikaitkan dengan Al-quran. Sungguh Allah mengetahui sedangkan kita tidak. Maka nikmat Tuhanmu mana lagi yang kamu dustakan. Lalu tidakkah kamu bersyukur? Dan beriman hanya kepada Allah SWT? Maka kita sebagai umatnya harus bersyukur, dan beriman kepada Allah serta menjaga kelestarian lingkungan kita agar bumi ini tetap kokoh dan jauh dari kerusakan.

Dalam beberapa hal penelitian dengan integrasi banyak juga ditemukan kekurangan, kurangnya informasi yang lebih detail serta tafsiran atau kajian secara Islam yang kurang mendalam. Dengan adanya penelitian mengenai integrasi Sains dan Islam semakin banyak pula informasi wawasan baru yang diperoleh maupun adanya masukan guna kesempurnaan penelitian mengani integrasi dalam penelitian ini maupun penelitian lainnya.

\section{SIMPULAN}

Alam semesta dan tata surya adalah ciptaan Allah. Alam semesta awalnya satu kesatuan kemudian berpisah dan menjadi langit dan bumi. Bumi berisi dengan segala mancam manfaat untuk makhluk -Nya demikian juga dengan langit. Bumi berisi sungai, gunung, air, tumbuhan dan lain sebagainya. Gunung dijadikan pasak pada bumi agar bumi ini tidak goncang dan terombang ambing.

Penciptaan langit dan tata surya juga sangat menakjubkan. Langit Allah ciptakan tujuh lapisan yaitu terdiri dari tujuh lapisan atmosfer yang memiliki fungi masing-masing. Allah ciptakan matahari bulan dan bintang. Allah jadikan malam dan siang. Semua hal yang ada dalam tata surya dan luar angkasa,bulan, matahari, bintang, dan planet lainnya mengorbit sesuai pada pusat edarnya.

\section{DAFTAR REFERENSI}

Abu Ja'far Muhammad bin Jarir Ath-Thabari. (2009). Jami' Al Bayan an Ta'wil Ayi AlQuran. Jakarta: Pustaka azzam.

Ahmad Khalid Allam. (2005). Al-Quran dalam Keseimbangan Alam dan Kehidupan. Jakarta: Gema Insani.

Amril. (2016). Epistimologi Integratif-Interkonektif Agama dan Sains. Jakarta: PT. Raja Grafindo Persada.

Badan Litbang. Lajnah Pentasihan Mushaf Qur'an. \& LIPI. (2010). Penciptaan Bumi dalam Perspektif Al-Quran dan Sains. Jakarta : Lajnah Pentasihan Mushaf Quran.

Badan Litbang. Lajnah Pentasihan Mushaf Qur'an. \& LIPI. (2010). Penciptaan Jagat Raya dalam Perspektif Al-Quran dan Sains. Jakarta : Lajnah Pentasihan Mushaf Quran. 
Badan Litbang. Lajnah Pentasihan Mushaf Qur'an. \& LIPI. (2010). Manfaat Benda-benda Langit dalam Perspektif Al-Quran dan Sains. Jakarta : Lajnah Pentasihan Mushaf Quran.

Caner Taslaman. (2006). Miracle Of The Quran: Keajaiban Al-Quran Mengungkap Penemuan-Penemuan Ilmiah Modern. Bandung: Mizan.

Departemen Agama RI, al-Qur'an dan Tafsirnya, Jilid 1 Juz 1,2,3,

Departemen Agama Republik Indonesia. (2004).Al-Qur'an dan Terjemahannya, (Jakarta: CV. Karya Insan Indonesia.

Hayat. (2013). Pengembangan KurikulumBaru. Bandung: Remaja Rosdakarya.

Muhammad Miftah. (2017). Model Integrasi Sain dan Agama.jurnal penelitian vol. 14, No. 2.No.

Saikh Abdurrahman bin Nashir as-Sa'di. (2012). Tafsir al-Quran (3). Surat: Al-A'raf-Yusuf. Jakarta: DARUL HAQ

Saikh Abdurrahman bin Nashir as-Sa'di. (2012). Tafsir al-Quran (5). Surat:Al-Mu'minunSaba'. Jakarta: DARUL HAQ

Saikh Abdurrahman bin Nashir as-Sa'di. (2012). Tafsir al-Quran (6). Surat:Fathir-qaf. Jakarta: DARUL HAQ

Shihab, M. Quraish, Membumikan al-Qur'an, Cet. ke-16, Bandung: Penerbit Mizan, 1997.

Yuli sectio. Pendidikan: Hakekat, Tujuan \& Proses.

Syaamil Al-Qur'an Terjemahan Per-Kata Type Hijaz.

Taifikurrahman. (2012). Kajian Tafsir di Indonesia, Mutawatir: Jurnal Keilmuan Tafsir hadis Volume 2, Nomor 1.

Quraish Shihab. (2000) Tafsir al-Misbah.Jakarta: Lentera Hati.

Zaghlul An-Najjar. (2011). Sains Dalam Hadis (Mengungkap Fakta Ilmiah Dari Kemukjizatan Hadis Nabi. Jakarta: AMZA 